\title{
CHARACTERIZATION AND ANTIMICROBIAL STUDIES OF FIVE SUBSTITUTED BIS-THIOUREAS
}

\author{
(Pencirian dan Kajian Antimikrobial Terhadap Lima Sebatian Bis-Tiourea) \\ Nurulain Kamalulazmy, Sahilah Abd Mutalib, Fatin Ilyani Nasir, Nurul Izzaty Hassan* \\ School of Chemical Sciences and Food Technology, \\ Faculty of Science and Technology, \\ Universiti Kebangsaan Malaysia, 43600 UKM Bangi, Selangor, Malaysia \\ *Corresponding author: drizz@ukm.edu.my
}

Received: 4 November 2015; Accepted: 4 January 2016

\begin{abstract}
Thioureas play an important role in medicinal chemistry and agricultures due to their biological activity such as antibacterial, antifungal, antiviral, herbicides, rodenticides, phenoloxidase enzymatic inhibitors, anti-HIV and anti-tumor agents. In this study, five substituted bis-thioureas have been synthesized. The isophataloyl chloride and 2,6- pyridinedicarbonyl dichloride were easily converted to bis-isothiocyanate compound via the reaction with ammonium thiocyanate by solid-liquid phase transfer catalysis of polyethylene glycol-400 (PEG-400). Bis-isothiocyanate compound was reacted with aniline derivatives to produce substituted bis-thioureas in good yield at room temperature. All the novel compounds were obtained as yellow solid after recrystallization using DMF/EtOH/ $\mathrm{H}_{2} \mathrm{O}$. Their $\mathrm{che} \mathrm{mical} \mathrm{structures} \mathrm{were} \mathrm{confirmed} \mathrm{by} \mathrm{Infrared} \mathrm{spectrosopy}$ (IR), Nuclear Magnetic Resonance (NMR) ${ }^{1} \mathrm{H}$ and ${ }^{13} \mathrm{C}$ and mass spectrometry. The five synthesized compounds were screened for antimicrobial activities using disc diffusion method for antimicrobial activity against Gram-positive bacteria (Bacillus Subtilis and Staphylococcus Aureus), Gram-negative bacteria (Escherichia Coli and Salmonella Typhi) and a mold (Aspergillus Niger). All tested compounds showed low antimicrobial activity since the diameter of inhibition zone (IZ) measure was less than positive control inhibition zone.
\end{abstract}

Keywords: bis-thiourea, antimicrobial activities, PEG-400

\section{Abstrak}

Sebatian tiourea memainkan peranan penting dalam kimia perubatan dan pertanian kerana sebatian ini mempunyai aktiviti biologi seperti antibakteria, antivirus, herbisid, rodentisid, perencat enzim fenoloksidase, anti-HIV dan agen anti-tumor. Lima sebatian bis-tiourea telah disintesis dalam kajian ini. Sebatian bis-isotiosianat disintesis dengan mudah melalui tindak balas di antara sebatian isofataloil klorida atau 2,6-piridinadikarbonil diklorida dengan ammonium tiosianat melalui pemindahan mangkin fasa pepejal-cecair polietilena glikol-400 (PEG-400). Seterusnya, sebatian bis-isotiosianat ditindak balas dengan sebatian amina bagi menghasilkan sebatian bis-tiourea dengan hasil yang baik pada suhu bilik. Semua sebatian diperolehi dalam bentuk pepejal bewarna kuning selepas penghabluran semula menggunakan pelarut DMF/EtOH/ $\mathrm{H}_{2} \mathrm{O}$. Pencirian struktur sebatian dibuat melalui kaedah spektroskopi Infra Merah (IR), Resonans Magnet Nukleus (NMR) ${ }^{1} \mathrm{H}$ dan ${ }^{13} \mathrm{C}$ dan spektrometer jisim (MS). Kajian aktiviti antimikrob bagi lima sebatian yang telah disintesis dibuat melalui kaedah resapan cakera melawan bakteria Gram positif (Bacillus Subtilis and Staphylococcus Aureus),bakteria Gram negatif (Escherichia Coli and Salmonella Typhi) dan kulat (Aspergillus Niger). Semua sebatian menunjukkan aktiviti antimikrob yang diperolehi rendah kerana diameter zon perencatannya (IZ) lebih kecil daripada zon perencatan kawalan positif.

Kata kunci: bis-tiourea, aktiviti antimikrob, PEG-400 


\title{
Introduction
}

Antimicrobial agents has received much attention in recent years due to the dramatically increased of bacterial and fungi infectious diseases. Since penicillin was introduced as antibiotics in 1940's and were among the first medications to be effective against many bacterial infections, antibiotics have been used widely in fight against infectious diseases caused by bacteria and fungi. However, the usage and misuse of antibiotics has led to the emergence of antibiotic-resistant pathogens including multidrug-resistant strains [1 - 3]. As consequence, it has caused failure in the treatment of infectious diseases. In that respect, there is growing interest in the discovery of new antibacterial agents.

Thioureas were first synthesized by Neuki in 1873 [4]. Thiourea derivatives exhibit various biological activities such as antiviral [5, 6], antibacterial [7], fungicidal [8, 9], herbicidal [10] and anti-HIV [11]. In 2011, Peng et al. have reported some 1,3-benzenedicarbonyl bisthiourea showed inhibition activities against cancer cells, such as human nasopharyngeal cancer cell line, $\mathrm{CNE}_{2}$ and human oral cavity cancer cell line, $\mathrm{KB}$ with $\mathrm{IC}_{50}$ value 10.72 and $9.91 \mu \mathrm{m}$ respectively [12].

Some example of bis-thiourea derivatives are $\mathrm{N}^{3}, \mathrm{~N}^{3}$-bis (disubstituted)isophatalyl-bis(thiourea), bis(thiourea)hydrazide [13], 2,2'-diaminobinapthalene-bis(thiourea) [14] and (bis)thiourea polyamine [15]. The derivatives of bis (disubstituted)isophtalayly-bis(thiourea) were also reported by Wang et al., Peng et al. and Jamil et al. research groups in 2005, 2011 and 2013, respectively [16, 17, 18]. In 2011, 1,2$\operatorname{Bis}\left(N^{\prime}\right.$-benzoylthioureidothioureido)-4-cholorobenzene was reported by Yamin research group [19]. The former compound is similar to 1,2-bis( $N^{\prime}$-benzoylthioureido)benzene reported by Thiam and co-workers [20] during 2008 except for the presence of 4-chlorobenzene bridge at 1,2 position that connected the two benzoyl thioureido group.

In view of these observations, we have designed 1,3-benzenedicarbonyl and 2,6-pyridinedicarbonyl bisthiourea derivatives in order to investigate their antimicrobial activities. Herein, we report the syntheses of five bisthioureas compound NA1-5 as shown in Figure 1 with the aid of solid-liquid phase transfer catalyst, PEG-400 [12]. Their structures of all the compounds were confirmed by IR spectroscopy and ${ }^{1} \mathrm{H}$ and ${ }^{13} \mathrm{C}$ Nuclear Magnetic Resonance (NMR). All compounds were screened for antimicrobial activities against Gram-positive bacteria, Gram- negative bacteria and a mold.<smiles>[R][I]1=C=CC=C(NC(=S)NC(=O)c2cccc(C(=O)NC(=S)Nc3ccccc3)c2)C=C1</smiles>

NA1: $\mathrm{R}=4-\mathrm{CH}_{3}$

NA2: $\mathrm{R}=3,5-\left(\mathrm{CF}_{3}\right)_{2}$<smiles>[R][I-]1=C=CC=C(NC(=S)NC(=O)c2cccc(C(=O)NC(=S)Nc3ccccc3)n2)C=C1</smiles>

NA3: $R=4-F$

NA4: $\mathrm{R}=4-\mathrm{CH}_{3}$

NA5: $\mathrm{R}=3,5-\left(\mathrm{CF}_{3}\right)_{2}$

Figure 1. Chemical structures of substituted bis(thioureas)

\begin{abstract}
Materials and Methods
Chemicals (isophataloyl chloride, 2,6-pyridinedicarbonyl dichloride, aniline, 4-fluoroaniline, 3,5bis(trifluoromethyl)aniline, ammonium thiocyanate, and PEG-400) and solvents (dichloromethane, dimethylformamide and ethanol) were purchased from Sigma Aldrich and MERCK and used directly without further purification. Melting points were determined by using BÜCHI Melting Point Model B-545. Infrared spectra were obtained using FTIR Perkin Elmer-1310 Spectrum GX Spectrophotometer in the spectral range of 4000
\end{abstract}


$-400 \mathrm{~cm}^{-1} \cdot{ }^{1} \mathrm{H}$ and ${ }^{13} \mathrm{C}$ were analysed by using Bruker Avance III $600 \mathrm{MHz}$ and Jeol JNM-ECP 400MHz NMR spectrometer.

\section{Synthesis of compounds}

The general procedure for synthesizing compounds NA1-5 (Scheme 1) was as follows. Isophataloyl chloride (2.46 $\mathrm{mmol})$ or 2,6-pyridinedicarbonyl dichloride $(2.45 \mathrm{mmol})$ was dissolved in $30 \mathrm{~mL}$ dichloromethane.

Subsequently, ammonium thiocyanate $(7.38 \mathrm{mmol})$ and PEG-400 $(0.22 \mathrm{mmol})$ were added to the solution and was stirred at room temperature for 2 hours. The resulting mixture was filtered to give isothiocyanate compound which was directly used without further purification. Aniline derivatives $(5.15 \mathrm{mmol})$ was added and stirred for another hour. The yellow precipitate formed was filtered and washed with distilled water and purified by recrystallization using Dimethylformamide/Ethanol/Water.

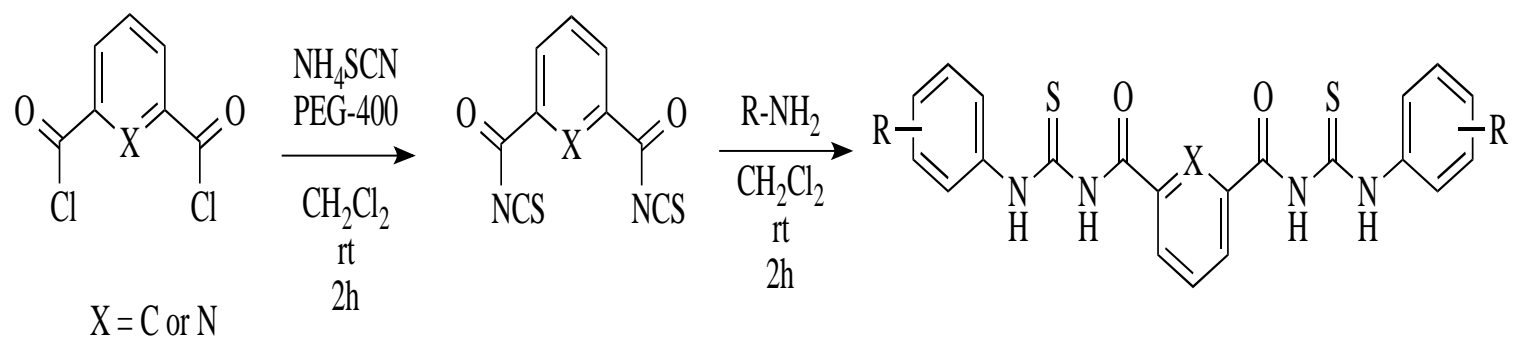

Scheme 1. Synthesis of bis(thiourea) derivatives

\section{Antibacterial screening}

All synthesized compounds were screened for their antimicrobial activity by using disc diffusion method against five microbs (Bacillus Subtilis, Staphylococcus Aureus, Escherichia Coli, Salmonella Typhi, and Aspergillus Niger). Streptomycin $(10 \mu \mathrm{g})$ and Kinamycin $(30 \mu \mathrm{g})$ were used as positive control and Dimethyl sulfoxide as negative control. All bacteria were cultured in nutrient broth and incubated at $37{ }^{\circ} \mathrm{C}$ for 24 hours. After that, the agar media was prepared by pouring the nutrient agar solution into the sterilized petri dishes. Then, the cultures were spread on the surface of Nutrient Agar (NA). The discs (6 mm diameter) were impregnated with $(10 \mu \mathrm{L} / \mathrm{disc})$ and $(30 \mu \mathrm{L} / \mathrm{disc})$ test samples and then placed on the surface of the agar media. Experimental plates were incubated at $37{ }^{\circ} \mathrm{C}$ for 24 hours. Antimicrobial activity was determined by measuring the diameter of inhibition zone (IZ) and compared with positive control.

\section{Results and Discussion}

In this study, bis-isothiocyanate compound was not isolated and directly treated with respective aniline derivatives to give the corresponding bis-thiourea (NA1-5) in moderate to good yield via nucleophilic substitution mechanism. IR studies showed that, strong absorption in region $3250-3383 \mathrm{~cm}^{-1}$, which corresponds to $v(\mathrm{~N}-\mathrm{H})$ stretching. The $v(\mathrm{C}=\mathrm{O})$ absorption bands were observed in region $1650-1687 \mathrm{~cm}^{-1}$. The medium intensity bands around $1152-1127 \mathrm{~cm}^{-1}$ attribute to the stretching of $v(\mathrm{C}=\mathrm{S})$. All absorptions band value was in agreement with standard absorption value for thiourea compounds.

In the ${ }^{1} \mathrm{H}$ NMR spectra, the CONH protons appear as singlet in the range of $\delta 12.3-12.4 \mathrm{ppm}$ whereas CONH protons appeared at $\delta 11.1-11.5 \mathrm{ppm}$. The appearance of $\mathrm{N}-\mathrm{H}$ signals at higher frequency was due to the presence of carbonyl and thiocarbonyl groups which exert strong deshielding effect. The aromatic protons of parent 1,3-benzenedicarboxamide appeared around $\delta 8.5-7.8 \mathrm{ppm}$. The aromatic protons of amine in compound NA1 and NA2 showed peaks in the range of $\delta 7.5-7.2 \mathrm{ppm}$ and $\delta 8.8-7.9 \mathrm{ppm}$ respectively. The protons signals of amine in NA2 were observed at higher frequency because the protons were deshielded by $\mathrm{CF}_{3}$ groups. Compounds with parent 2,6-pyridinedicarboxamide protons signals were found at $\delta 8.0-7.5 \mathrm{ppm}$ while aromatic protons of amine in compound NA3, NA4 and NA5 appeared at $\delta 8.5-6.8$ $\mathrm{ppm}$. The aromatic protons signals of amine in compound NA3, NA4 and NA5 were slightly different from each other may be influenced by the nature of substituent group attached to the compound. Electronegative 
atom reduced the electron density around those protons and hence the protons were deshielded. The ${ }^{13} \mathrm{C}$ NMR assignments showed that, the carbon signals for $(C=S)$ and $(C=O)$ appeared at $\delta 180.0-178.0 \mathrm{ppm}$ and $167.2-162.0 \mathrm{ppm}$ respectively. While aromatic carbon signals were observed at $\delta 154.1-116.9 \mathrm{ppm}$. All compounds were obtained as yellow solid after recrystallization using DMF/EtOH/ $\mathrm{H}_{2} \mathrm{O}$. Their chemical structures were validated by FTIR, ${ }^{1} \mathrm{H}$ and ${ }^{13} \mathrm{C}$ NMR. The physical and spectroscopic data of the new compounds are shown below.

1,3-Benzenedicarboxamide, $N^{1}, N^{3}$-bis[[(4-methylphenyl)amino]thioxomethyl] NA1: Yield 78\%, Yellow solid, m.p $222.0^{\circ} \mathrm{C}$, IR $\left(\mathrm{KBr}\right.$ pellet, $\left.\mathrm{cm}^{-1}\right)$ : v (N-H) 3250.1, v $(\mathrm{C}=\mathrm{O})$ 1655.9, v (C-N) 1253.1, v (C=S) 1151.0, ${ }^{1} \mathrm{H}\left(\mathrm{DMSO}_{6}\right)^{\delta} \mathrm{H}(\mathrm{ppm}): 12.4(\mathrm{~s}, 2 \mathrm{H}, \mathrm{CSNH}), 11.5(\mathrm{~s}, 2 \mathrm{H}, \mathrm{CONH}), 8.5(\mathrm{~s}, 1 \mathrm{H}, \mathrm{Ar}-\mathrm{H}), 8.18(\mathrm{~d}, \mathrm{~J}=5.6 \mathrm{~Hz}$, 2H, Ar-H), $7.8(\mathrm{t}, \mathrm{J}=8 \mathrm{~Hz}, 1 \mathrm{H}, \mathrm{Ar}-\mathrm{H}), 7.56(\mathrm{~d}, \mathrm{~J}=8.4 \mathrm{~Hz}, 4 \mathrm{H}, \mathrm{Ar}-\mathrm{H}), 7.24(\mathrm{~d}, \mathrm{~J}=8.0 \mathrm{~Hz}, 4 \mathrm{H}, \mathrm{Ar}-\mathrm{H}), 2.3(\mathrm{~s}$, $\left.6 \mathrm{H}, \mathrm{CH}_{3}\right),{ }^{13} \mathrm{C}\left(\mathrm{DMSO}-\mathrm{d}_{6}\right){ }^{\delta} \mathrm{C}(\mathrm{ppm}): 179.3(\mathrm{C}=\mathrm{S}), 167.7(\mathrm{C}=\mathrm{O}), 136.3$ (Ar-C), 135.8 (Ar-C), 133.7 (Ar-C), 132.4 (Ar-C), 129.7 (Ar-C), 129.3 (Ar-C), 124.8 (Ar-C), $21.1\left(\mathrm{CH}_{3}\right)$.

1,3-Benzenedicarboxamide, $\quad N^{1}, N^{3}$-bis[[(3,5-bis(trifluoromethyl(phenyl))amino]thioxomethyl $\quad$ NA2: Yield $72 \%$, Yellow solid, m.p $195.6^{\circ} \mathrm{C}$, IR (KBr pellet, $\left.\mathrm{cm}^{-1}\right): v(\mathrm{~N}-\mathrm{H}) 3232.8, v(\mathrm{C}=\mathrm{O}) 1656.1$, v (C-N) 1245.8, v $\left(\mathrm{Ar}-\mathrm{CF}_{3}\right)$ 1280.0, v $(\mathrm{C}=\mathrm{S}) 1127.0,{ }^{1} \mathrm{H}\left(\mathrm{DMSO}_{-} \mathrm{d}_{6}\right)^{\delta} \mathrm{H}(\mathrm{ppm}): 8.8(\mathrm{~s}, 1 \mathrm{H}, \mathrm{Ar}-\mathrm{H}), 8.5(\mathrm{~s}, 4 \mathrm{H}, \mathrm{Ar}-\mathrm{H}), 8.4(\mathrm{~d}, \mathrm{~J}$ $=6.6 \mathrm{~Hz}, 2 \mathrm{H}, \mathrm{Ar}-\mathrm{H}), 7.9(\mathrm{~s}, 2 \mathrm{H}, \mathrm{Ar}-\mathrm{H}), 7.8(\mathrm{t}, \mathrm{J}=7.2 \mathrm{~Hz}, 7.8 \mathrm{~Hz}, 1 \mathrm{H}, \mathrm{Ar}-\mathrm{H}),{ }^{13} \mathrm{C}\left(\mathrm{DMSO}-\mathrm{d}_{6}\right){ }^{8} \mathrm{C}(\mathrm{ppm}): 180.0$ $(\mathrm{C}=\mathrm{S}), 167.1(\mathrm{C}=\mathrm{O}), 140.1$ (Ar-C), 133.4 (Ar-C), 132.5 (Ar-C), 131.7-131.0 (q, $\left.{ }^{3} \mathrm{~J}_{\mathrm{CE}}=33.9 \mathrm{~Hz}, \mathrm{C}_{-} \mathrm{CF}_{3}\right)$, 129.6 (Ar-C), 127.9 (Ar-C), 126.0-120.6 (q, $\left.{ }^{1} \mathrm{~J}_{\mathrm{CF}}=270.1 \mathrm{~Hz}, \mathrm{CF}_{3}\right), 119.5$ (Ar-C).

2,6-pyridinedicarboxamide, $N^{1}, N^{3}$-bis[[(4-fluorophenyl)amino]thioxomethyl] NA3: Yield 53\%, Yellow solid, m.p $210.4{ }^{\circ} \mathrm{C}$, IR $\left(\mathrm{KBr}\right.$ pellet, $\left.\mathrm{cm}^{-1}\right): v(\mathrm{~N}-\mathrm{H})$ 3383.6, v (C=O) 1679.7, v (C-N) 1227.8, v (C-F) $1352.8 v$ $(\mathrm{C}=\mathrm{S}) 1151.0,{ }^{1} \mathrm{H}\left(\mathrm{DMSO}_{\mathrm{d}}\right){ }^{\delta} \mathrm{H}(\mathrm{ppm}): 8.0(\mathrm{~d}, \mathrm{~J}=7.8 \mathrm{~Hz}, 2 \mathrm{H}, \mathrm{Ar}-\mathrm{H}), 7.94(\mathrm{t}, \mathrm{J}=8.4 \mathrm{~Hz}, 7.2 \mathrm{~Hz}, 1 \mathrm{H}, \mathrm{Ar}-$ $\mathrm{H})$, 7.27-7.25 (m, 4H, Ar-H), 6.88-6.83 (m, 4H, Ar-H), ${ }^{13} \mathrm{C}$ (DMSO-d ${ }_{6}{ }^{\delta} \mathrm{C}(\mathrm{ppm}): 178.9(\mathrm{C}=\mathrm{S}), 163.7$ $(\mathrm{C}=\mathrm{O}), 160.9-159.3\left(\mathrm{~d},{ }^{1} \mathrm{~J}_{\mathrm{EC}}=242.8 \mathrm{~Hz}, \mathrm{C}-\mathrm{F}\right), 149.3$ (Ar-C), 140.4 (Ar-C), 134.4 (Ar-C), 127.1-127.0 (d, $\left.{ }^{3} \mathrm{~J}_{\mathrm{EC}}=8.8 \mathrm{~Hz}, \mathrm{Ar}-\mathrm{C}\right), 126.9(\mathrm{Ar}-\mathrm{C}), 115.4-115.5\left(\mathrm{~d},{ }^{2} \mathrm{~J}_{\mathrm{EC}}=21.9 \mathrm{~Hz}, \mathrm{Ar}-\mathrm{C}\right)$.

2,6-pyridinedicarboxamide, $N^{1}, N^{3}$-bis[[(4-methylphenyl)amino]thioxomethyl] NA4: Yield 65\%, Yellow solid, m.p $177.0{ }^{\circ} \mathrm{C}$, IR $\left(\mathrm{KBr}\right.$ pellet, $\left.\mathrm{cm}^{-1}\right)$ : v (N-H) 3280.7, v (C=O) 1656.0, v (C-N) 1241.8, v (C=S) 1144.2, $\mathrm{H}\left(\mathrm{DMSO}-\mathrm{d}^{6}\right){ }^{\delta} \mathrm{H}(\mathrm{ppm}): 12.3(\mathrm{~s}, 1 \mathrm{H}, \mathrm{CSNH}), 11.7$ (s, 1H, CSNH), 11.1 (s, 1H, CONH), 10.9 (s, $1 \mathrm{H}, \mathrm{CONH}), 8.2(\mathrm{t}, \mathrm{J}=8.4 \mathrm{~Hz}, 7.2 \mathrm{~Hz}, 1 \mathrm{H}, \mathrm{Ar}-\mathrm{H}), 7.7(\mathrm{~d}, \mathrm{~J}=8.0 \mathrm{~Hz}, 4 \mathrm{H}), 7.6(\mathrm{~d}, \mathrm{~J}=8.4 \mathrm{~Hz}, 1 \mathrm{H}, \mathrm{Ar}-\mathrm{H}), 7.5$ $(\mathrm{d}, \mathrm{J}=1,8.4 \mathrm{~Hz}, 1 \mathrm{H}, \mathrm{Ar}-\mathrm{H}), 7.2(\mathrm{~d}, \mathrm{~J}=8.0 \mathrm{~Hz}, 4 \mathrm{H}, \mathrm{Ar}-\mathrm{H}), 2.3\left(\mathrm{~s}, 6 \mathrm{H}, \mathrm{CH}_{3}\right),{ }^{13} \mathrm{C}\left(\mathrm{DMSO}_{6} \mathrm{~d}_{6}{ }^{\delta} \mathrm{C}(\mathrm{ppm}): 179.0\right.$ $(\mathrm{C}=\mathrm{S}), 166.9$ (C=O), 154.1 (Ar-C), 140.6 (Ar-C), 138.8 (Ar-C), 134.4 (Ar-C), 130.4 (Ar-C), 129.4 (Ar-C), 126.4 (Ar-C), $25.7\left(\mathrm{CH}_{3}\right)$.

2,6-pyridinedicarboxamide, $N^{1}, N^{3}$-bis[[(3,5-bis(trifluoromethyl(phenyl))amino]thioxomethyl] NA5: Yield $62 \%$, Yellow solid, m.p $345.5{ }^{\circ} \mathrm{C}$, IR $\left(\mathrm{KBr}\right.$ pellet, $\left.\mathrm{cm}^{-1}\right)$ : v (N-H) 3296.0, v (C=O) 1687.1, v $\left(\mathrm{Ar}_{-} \mathrm{CF}_{3}\right)$ 1283.1, v (C-N) 1246.6, v (C=S) 1151.8, ${ }^{1} \mathrm{H}\left(\text { Acetone- }_{6}\right)^{8} \mathrm{H}(\mathrm{ppm}): 11.1(\mathrm{~s}, 2 \mathrm{H}, \mathrm{CONH}), 8.7(\mathrm{~s}, 4 \mathrm{H}, \mathrm{Ar}-\mathrm{H})$, $8.5(\mathrm{~d}, \mathrm{~J}=7.8 \mathrm{~Hz}, 2 \mathrm{H}, \mathrm{Ar}-\mathrm{H}), 8.4(\mathrm{t}, \mathrm{J}=7.2 \mathrm{~Hz}, 7.8 \mathrm{~Hz}, 1 \mathrm{H}, \mathrm{Ar}-\mathrm{H}), 7.8(\mathrm{~s}, 2 \mathrm{H}, \mathrm{Ar}-\mathrm{H}),{ }^{13} \mathrm{C}$ (Acetone- $\left.\mathrm{d}_{6}\right){ }^{\delta} \mathrm{C}$ (ppm): $178.8(\mathrm{C}=\mathrm{S}), 162.0(\mathrm{C}=\mathrm{O}), 148.4$ (Ar-C), 140.4 (Ar-C), 140.2 (Ar-C), 140.1 (Ar-C), 132.0-131.4 (q , $\left.{ }^{3} \mathrm{~J}_{\mathrm{EC}}=33.0 \mathrm{~Hz}, \mathrm{C}-\mathrm{CF}_{3}\right), 126.0(\mathrm{Ar}-\mathrm{C}), 126.2-122.6\left(\mathrm{q},{ }^{1} \mathrm{~J}_{\mathrm{EC}}=270.0 \mathrm{~Hz}, \mathrm{CF}_{3}\right), 120.1$ (Ar-C), 116.9 (Ar-C).

\section{Antimicrobial activities}

The antibacterial and antifungal activities of five new bisthioureas were tested against two Gram-positive bacterias (Staphylococcus Aureus, Bacillus Subtilis), two Gram-negative bacterias (Escherichia Coli and Salmonella Typhi) and single fungal strain - Aspergillus Niger using disc diffusion method. Streptomycin and Kinamycin were used as positive controls (Table 1). 
Table 1. Antimicrobial result for five bis-thiourea compounds

\begin{tabular}{|c|c|c|c|c|c|c|c|c|c|c|}
\hline \multirow{4}{*}{ Compound } & \multicolumn{10}{|c|}{ Bacteria Inhibition Zone (mm) } \\
\hline & \multicolumn{10}{|c|}{ Concentration $(\mu \mathrm{g} / \mathrm{disc})$} \\
\hline & \multicolumn{2}{|c|}{ A.Niger } & \multicolumn{2}{|c|}{ B.Subtilis } & \multicolumn{2}{|c|}{ S.Aureus } & \multicolumn{2}{|c|}{ E.Coli } & \multicolumn{2}{|c|}{ S.Typhi } \\
\hline & $10 \mu \mathrm{g}$ & $30 \mu \mathrm{g}$ & $10 \mu \mathrm{g}$ & $30 \mu \mathrm{g}$ & $10 \mu \mathrm{g}$ & $30 \mu g$ & $10 \mu \mathrm{g}$ & $30 \mu \mathrm{g}$ & $10 \mu \mathrm{g}$ & $30 \mu \mathrm{g}$ \\
\hline NA1 & - & - & 6.5 & 6.5 & 7.0 & 7.0 & 6.5 & 6.5 & - & - \\
\hline NA2 & - & - & 6.5 & 6.5 & 7.0 & 7.0 & 6.5 & 6.5 & - & - \\
\hline NA3 & - & - & 7.5 & 7.5 & 7.0 & 7.0 & 6.5 & 6.5 & - & - \\
\hline NA4 & - & - & 6.5 & 6.5 & 6.5 & 6.5 & 6.5 & 6.5 & 6.5 & 6.5 \\
\hline NA5 & - & - & 7.0 & 7.0 & 6.5 & 6.5 & 6.5 & 6.5 & 8.0 & 9.0 \\
\hline Streptomycin $10 \mu \mathrm{g}$ & & & & & 16 & & 18 & .0 & 18 & .0 \\
\hline Kinamycin $30 \mu \mathrm{g}$ & & & & & 20 & & 24 & & 24 & .0 \\
\hline
\end{tabular}

Unfortunately, tested compounds did not display a remarkable activity against both type of bacteria and fungi. Nevertheless, compound NA5 showed valuable inhibitory activity. The activity of these compounds might be attributed to the presence of high electronegative substituent which enhanced the lipophilicity of the compounds. The lipophilicity of the compounds plays an important role in the penetration of solutes into the bacterial cell tissue [13]. The antibacterial activity of compound NA5 was higher than NA3 because NA5 contained multi fluoro group substituents which increase the lipophilicity of this compound. In contrary, all tested compounds had no activity against gram-negative bacteria. This observations showed that, the compounds were generally had better permeability towards gram-negative bacteria cell tissue.

Based on the test results, tested compounds had very low inhibition zone (IZ) values. It is known that thiourea compounds were generally exhibit good antimicrobial activities. However in this study, the results were contrary. This might be due to the solubility of the target compounds on the surface of the agar medium. Thus, the compounds were suspended on the agar surface and cannot reacted against those bacterias

\section{Conclusion}

In conclusion, five derivatives of 1,3-benzenedicarboxamide and 2,6-pyridinedicarboxamide bis-thiourea have been synthesized via solid-liquid phase transfer catalysis of PEG-400 and characterized by FTIR, ${ }^{1} \mathrm{H}$ and ${ }^{13} \mathrm{C}$ NMR. The preliminary studies on the antimicrobial activity via disc diffusion method showed that NA5 exhibit potential activity against Staphylococcus Aureus. For further research, we are planning to investigate the effect of transition metal complexation with these compounds toward their antimicrobial activity as some reports demonstrated that bis-thioureas antimicrobial activity were enhanced when complexed with transition metal. In addition, more sensitive antibacterial screening method such as dilution method should be used to evaluate the potential of synthesized compounds.

\section{Acknowledgement}

The authors would like to thank Universiti Kebangsaan Malaysia and the Ministry of Higher Education, Malaysia, for research grants FRGS/2/2013/ST01/UKM/02/1 and GUP-2014-015 respectively. Research facilities provided by PPSKTM and the Centre of Research and Instrumentation (CRIM) are very much appreciated.

\section{References}

1. Neucki, M. (1873). Zur kenntniss des sulfoharnstoffs. Berichte der Deuschen Chemischen Gesellschaft, 6 (1): $598-600$. 
2. Neu, H. C. (1992). The crisis in antibiotic resistance. Science, 257: $1064-1073$.

3. Michel, M. and Gutmann, L. (1997). Methicillin-resistant Staphyllococus aureus and vancomycinresistant enterococci: therapeut realities and possibilities. Lancet, 349: 1901-1906.

4. Normark, B. H. and Normark, S. (2002). Evolution and spread of antibiotic resistance. Journal of Internal Medicine, 252: 91 - 106.

5. Sun, J., Cai, H. and Mei et al. (2010). Molecular docking and QSAR studies on substituted acyl(thio)urea and thiadiazolo [2,3-a] pyrimidine derivatives as potent inhibitors of influenza virus neuraminidase. Chemical Biology and Drug Design, 76 (3): 245 - 254.

6. Sun, C., Zhang, X., Huang, H. and Zhou, P. (2006). Synthesis and evaluation of a new series of substituted acyl(thio)urea and thiadiazolo [2,3-a] pyrimidine derivatives as potent inhibitors of influenza virus neuraminidase. Bioorganic and Medicinal Chemistry, 14 (24): 8574 - 8581.

7. Zhong, Z., Xing, R., Liu, S., Wang, L., Cai, S. and Li, P. (2008). Synthesis of acyl thiourea derivatives of chitosan and their antimicrobial activities in vitro. Carbohydrate Research, 343 (3): 566 570.

8. Wang, F. H., Qin, Z. L. and Huang, Q. (2006). Synthesis and fungicidal activity of 1,3,4-oxadiazole substituted acylthioureas. Frontiers of Chemistry in China, 1: 112.

9. Ke, S. Y. and Xue, S. J. (2006). Synthesis and herbicidal activity of N(O)thioureas derivatives and related fused heterocyclic compounds. Arkivoc, 10: $63-68$.

10. Xiao, L., Liu, C. J. \& Li, Y. P. (2009). Ultrasound Promoted Synthesis of Bis(substituted pyrazol-4ylcarbonyl)-Substituted Thioureas. Molecules, 14(4): 1423 -1428.

11. Vig, R., Mao, C., Venkatachalam, T. K., Tuel-Ahlgren, L., Sudbeck, E. A. and Uckun, A. (1998). Rational design and synthesis of phenethyl-5-bromopyridyl thiourea derivatives as potent nonnucleoside inhibitors of HIV reverse transcriptase. Bioorganic and Medicinal Chemistry, 6 (10): 1789 1797.

12. Peng, H., Liang, Y., Chen, L., Fu, L., Wang, H. and He, H. (2011). Efficient Synthesis and Biological Evaluation of 1,3-benzenedicarbonyl dithioureas. Bioorganic \& Medicinal Chemistry Letters, 21: 1102 1104.

13. Klein, J. J. and Hecht, S. (2012). Synthesis of a new class of bis(thiourea)hydrazide pseudopeptides as potential inhibitors of $\beta$-sheet aggregation. Organic Letters 14 (11): 330 - 333.

14. Rampalakos, C. and Wulff, D. D. (2008). A Novel Bis-Thiourea Organocatalyst for the Asymmetric AzaHenry Reaction. Advanced Synthesis \& Catalysis, 350 (11-12): 1785 - 1790.

15. Verlinden, B. K., Beer de, M., Pachaiyappan, B., Besaans, E., Andayi, W. A., Reader, J., Niemand, J., Biljon van, R., Guy, K., Egan, T., Woster, P. M. \& Birkholtz, L-M. (2015). Interrogating alkyl and arylalkylpolyamino (bis)urea and (bis)thiourea isosteres as potent antimalarial chemotypes against multiple lifecycle forms of Plasmodium falciparum parasites. Bioorganic \& Medicinal Chemistry, 23 (16): 5131 5143.

16. Takacs-Novak, K., Noszal, B., Hermecz, I., Kereszturi, G., Podanyi, B. and Szasz, G. (1990). Protonation Equilibria of Quinolone. Antibacterials. Journal of Pharmaceutical Sciences, 79 (11): 1023 1028.

17. Xicun, W., Juan, L. and Zheng, L. (2005). An expenditious and solvent-free approach to substituted bisthioureas and bis-thiosemicarbazides. Journal of Chemical Research, $791-792$.

18. Jamil, M., Zubair, M., Farid, M. A., Rashid, U., Rasool, N. and Islam, S. (2013). Antibacterial, cytotoxicity studies and characterization of some newly synthesized symmetrical $N^{3}, N^{3}$-Bis (disubstitued)isophathalyl-bis(thioureas) and their $\mathrm{Cu}(\mathrm{II})$ and $\mathrm{Ni}$ (II) complexes. Journal of Chemistry, Hindawi.

19. Yamin, B. M. and Osman, U. M. (2011). Acta Cryst. E67, o1286.

20. Thiam, E. I., Diop, M., Gaye, M., Sall, A. S. and Barry, A. H. (2008). Acta Cryst. E64, 0776. 